\title{
Freedom as a Problem of Legal Consciesness: Social and Philosophic Aspects of the Problem in the Global World
}

\author{
Anton A. Efarkin* \\ Siberian Federal University \\ 79 Svobodny, Krasnoyarsk, 660041, Russia
}

Received 10.01.2015, received in revised form 19.02.2015, accepted 28.03.2015

Special aspects of freedom manifestation in the modern society are studied in the article. The author proves that it is closely connected to the level of legal awareness and involves socio-philosophical level of analysis. In particular, it is proved that the idea of freedom in Russia has mental and historical aspects that have formed the modern complex of problems in the legal sphere.

In the modern global society there appeared a need in a profound and detailed study of the characteristics of freedom and unfreedom in social and philosophical aspect. However, it is useless to count on successful solution of the problems of legislation improvement without formation of legal consciousness among the whole population.

Freedom has always coexisted with legal nihilism. The point is that legal nihilism in its numerous manifestations and forms, from underestimation and lack of respect to right until its absolute ignoring and denial is antipode of legal culture. Legal nihilism is always state nihilism, as the denial of right also essentially includes denial of state as legal organization of public authority. Legal nihilism has widely spread in many countries, including Russia.

Despite the fact that the problem of freedom deprivation was not the subject of the Russian conventionalists' direct attention, they identified its characteristics and characterized its main ideas. Laws, in their opinion, develop from the mental source that represents a complex and multifaceted formation, represented by the laws of natural being, including the laws of mental activity from the conscious to the unconscious.

In the global world new tendencies that concern freedom and its deprivation appear. Studying the essence of human freedom, it is possible to talk about certain similarity between the international mission of Russia, designed to disseminate the truth and justice all over the world (based on Orthodoxy and autocracy under the tsars - Russian God-bearing people, on the basis of social justice in the Marxist-Leninist understanding in the spirit of proletarian internationalism during the Soviet era). Finally, the parallels between the tsarist and Soviet regimes that also suggest themselves to the public and political sphere are obvious.

Globalization has also caused the growth of international intergovernmental and non-governmental organizations, which are aimed to protect man both in everyday situations and in the period of his imprisonment. Migrants, foreign tourists and high-class professionals (lawyers, journalists, engineers, architects, scientists, who tend to have cosmopolitan attitudes and way of life) are referred to the other types of transnational factors, which have a growing impact on the problem of deprivation of freedom. It is not just complexity of deprivation of freedom of man who has, for example, dual citizenship, but also different ideas about the necessity of deprivation of liberty as educational function of society.

\footnotetext{
(C) Siberian Federal University. All rights reserved

* Corresponding author E-mail address: efar@mail.ru
} 
Problems connected with deprivation of liberty are also closely connected with a certain system of values, which is the leading one for a particular society. To comprehend the essence of freedom and unfreedom there appears the need to consider another important factor. Since archetypes are stable and are the main elements of the unconscious, it is possible to suppose that as a result of their influence upon legal awareness, special elements that have stable contents - the basic stereotypes of justice, appear. Elements that include basic fundamental provisions and prototypes of justice, represented in the rational form can be referred to them. All this fundamentally affects understanding of freedom and unfreedom in the global world.

An important execution of freedom consists in following the idea of perfection. This idea is the basis of social consciousness of the collectivist societies.

Keywords: freedom, legal consciousness, ethicocentrism, legal nihilism, natural right, inclusive state.

Research area: philosophy.

Topicality of the study of problems connected to deprivation of freedom is determined by communication trends of the global world. Development of definition of the term "freedom" reflects the latest aspects in this field of knowledge based upon identification of its place in the system of public consciousness.

An important characteristic of the Russian notions of freedom is that they constantly, in various degrees, are influenced by the collective unconscious. In particular, the collective unconscious affects conscious through myths. Therefore, if the unconscious affects legal consciousness, then if not the developed legal mythology, but a significant number of legal myths should be present in the public conscience. At that, verbal content of myths itself is a part of religious or cultural consciousness, and legal consciousness is influenced by its hidden, unconscious contents. In practice, this means that the ideas of freedom and unfreedom were formed on the basis of mythological consciousness, and were continued in everyday practice.

A person has legal consciousness, regardless whether he knows it or not, values it, or have alienated attitude towards legal consciousness. "All human life and his fate are formed with the participation of legal consciousness and under its leadership. Moreover, for a person to live in a society means to live by legal consciousness, in its function, in its terms, as it is always one of the great and necessary forms of human life. It lives in the soul and at the time of the absence of positive law when no authority has spoken out about the law and eternal behavior yet. This reveals a kind of tragicomedy of legal life: ugly, perverse legal consciousness remains legal consciousness, but distorts its content; it refers to the idea of right, but takes only a scheme from it, uses it in its own way, abuses it and fills it with unworthy, perverse content; there appears a "wrong right", which is, however, called "right" and is misinterpreted as right, compromising the idea in people's minds and undermining faith in it. Such a tragicomedy is characteristic not only of justice; it is a tragicomedy of all the spiritual life" [5].

Freedom has always coexisted with legal nihilism. The point is that legal nihilism in its numerous manifestations and forms, from underestimation and lack of respect to right until its absolute ignoring and denial is antipode of legal culture. Legal nihilism is always state nihilism, as the denial of right also essentially includes denial of state as legal organization of public authority. Legal nihilism has widely spread in many countries, including Russia. Centuries-old traditions of the despotic rulers' absolute power 
(from tsars to the Bolsheviks) and lawlessness of people played an important role in it.

Studying freedom, it is essential to take into account another important aspect. It took a hundred years to release the main part of Russian population - the peasantry from serfdom. At that, the release happened without granting land to the peasants (instead the system of communal land ownership - with large dependence of a single farmer from the community functioned). The key issue for Russia - the land question was not solved either with the king, nor the Bolsheviks and still remains one of the most important and complex problems of the entire process of contemporary socio-economic, political and legal reforms in the country.

Despite the fact that theproblemofdeprivation of freedom was not subject to the immediate attention of the Russian conventionalists, they identified its characteristics and characterize the main ideas. Laws, in their opinion, are developed from the mental source that is a complex and multifaceted formation, represented by the laws of natural being, including the laws of mental activity from the conscious to the unconscious. The supreme power is understood by the conventionalists as embodiment of the Divine Will, manifested in state authority, and the supreme truth, respectively, is expressed by the state in right. The logics of the conventionalists' judgment make it possible to suggest that they understood legal consciousness on the basis of not only legal, but also state ideas that in their ideas it had formal and legal, and mainly state and legal orientation. This is explained by the fact that state was understood as an idea that naturally presents in legal awareness, along with legal ideas; and real state and its form of governance are embodiment of these ideas. The conventionalists' opinions are based on the idea of nationality, which is understood as the authority's expression of needs of people and correspondence of the authority to its customs and traditions, as well as obedience of people to this power, as it is from God. According to the representatives of this trend, the main features of legal consciousness are ethicocentrism and exceptional ethical orientation.

Analyzing the limits of freedom, V.S. Solovyov believed that man has a general ultimate need for wholehearted or absolute life. "The Justification of the Good" [9] is dedicated to father, grandfather, priest Mikhail Vasilievich. "The work is subtitled "Moral Philosophy" and Solovyov sees the goal of human history in transformation of the world. However, Solovyov understood transformation of man and humanity in not quite Christian tradition, advocating to "theurgic doing" - participation of humanity in divine providence implementation, to transformation of the mundane realm into the Kingdom of God. This "freedom" induced the philosopher to create a utopian project of connecting Orthodoxy and Catholicism into "free theocracy". But, according to Tolstoy who highly appreciated Solovyov, his "energy of delusion" retreated to the common pathos and the philosopher's hope that mankind sooner or later will be free from the destructive power of individualistic delusions.

The problem of freedom is also closely connected to the problem of the constitutional state. Vladimir Solovyov and Leo Tolstoy in their criticism of "soulless" right became spokesmen of the general sense of frustration and doubt in the value of the constitutional state. Ardent hopes of the politicians and thinkers of the era of bourgeois revolutions to adopt the absolute "rule of reason" on the earth, that embodies the great principles of liberty, equality and brotherhood, were replaced by the end of the $19^{\text {th }}$ century by pessimistic recognitions of the illusory nature of the original ideas.

In the works by P.I. Novgorodtsev that followed the development of the natural law 
theory, a wide range of political doctrines that marked the course of the definition of legal consciousness in the $19^{\text {th }}$ century was studied. It is clear that the problem of freedom hold a prominent place here. It is possible to agree with P.I. Novgorodtsev, who believes that the depth of the crisis that overtook legal consciousness is revealed in the very characteristic of the early $20^{\text {th }}$ century assurances of irrelevance of right as a whole, the impotence of the external political forms and institutions in their desire to aspire to the field of moral life above the violent frames of legal law, without legal guarantees. Quite clearly his attitude towards the problem of freedom, unfreedom, opinion, etc.

Ideas about freedom as a fundamental component of legal consciousness are canonized in Russian pre-revolutionary literature, in the works by Konstantin Leontiev, Pavel Novgorodtsev, Ivan Ilyin, Leon Petrazycki, Bogdan Kistyakovsky. They boil down to the fact that legal consciousness was forced to reckon with the law and submit to it as a result. Legal consciousness awareness experienced legal response, it recognized the force of right, but not its dignity, and it did not generate the will to right based upon the will to its purpose. Moreover, legal consciousness fixed the will to lawlessness in itself as well as conviction that everything is allowed for power. The falsity of such a position manifested itself, in particular, in a false conception of freedom and the need for its restrictions.

In the modern global world order, new tendencies connected to freedom and its deprivation appear. Studying the essence of human freedom, it is possible to talk about certain similarity between the international mission of Russia, intended to disseminate truth and justice all over the world (on the basis on Orthodoxy and autocracy under the tsars - Russian God-bearing people, on the basis of social justice in the Marxist-Leninist understanding and in the spirit of proletarian internationalism during the Soviet era). Finally, quite obvious parallels between the tsarist and Soviet regimes are suggested in the state-political sphere.

Modern technology has seriously changed peoples' life, extending the limits of freedom, but there appeared problems, as the researchers note: "We got absorbed in playing technologism. An unpaid thing, a thought, a discussion, something that does not lead directly to career, success and to advancement in pragmatic direction, does not inspire at all. Intellectuals in general, and patriotic ones in particular, has taken pragmatic position concerning thoughts. Technologism has corrupted all of them" [4].

Nowadays, analytical study of the problems of deprivation of liberty allows identifying some basic forms of their manifestation, which more often attract researchers' attention and which study makes it possible to understand the essence of the phenomenon better.

Globalization has also caused the growth of international intergovernmental and nongovernmental organizations, which are aimed to protect man both in everyday situations and in the period of his imprisonment. Migrants, foreign tourists and high-class professionals (lawyers, journalists, engineers, architects, scientists, who tend to have cosmopolitan attitudes and way of life) are referred to the other types of transnational factors, which have a growing impact on the problem of imprisonment. It is not just complexity of deprivation of freedom of a man who has, for example, dual citizenship, but also different ideas about the necessity of deprivation of liberty as educational function of society.

Study of the essence of freedom and unfreedom as the leading phenomena of social life involves analysis of the problems of the nature of legal consciousness and its interrelation with the categories of "freedom" and "unfreedom". Along with that, the connection between freedom and 
legal consciousness is determined by the complex tendencies in the development of civilized man. The necessity to include freedom into the sphere of formal law requires a certain life experience, one way or another connected with the ideas that were formed during this period in a particular society. The point is that the ideas of freedom and unfreedom were formed at the level of mythological consciousness, and were continued in everyday practice that has its own historical specificity in Russia. In particular, in Russian society freedom has always coexisted with legal nihilism, which is manifested in various forms from underestimation and lack of respect to right to its absolute ignoring and denial. Legal nihilism is always the state of nihilism as well, as denial of right includes, in general, denial of state as legal organization of public authority. Despite the traditional cult of right as the main regulator of public life in Western countries, legal nihilism has widely spread in many countries, what is connected with the specific system of values of individualistic societies that were formed in the modern era. At the same time, in collectivist societies, where social norms are the main regulator, not freedom, but perfection comes to the forefront.

When studying freedom, it is important to take into account another important aspect. Despite the fact that the problem of deprivation of liberty was not subject to the immediate attention of Russian philosophers, they identified its characteristics and characterized its basic ideas. The laws are developed from the mental source, which is a complex and multifaceted formation, represented by the laws of natural being, including the laws of mental activity from the conscious to the unconscious.

Freedom mustbe studied as an integral feature of the continuity of Russian legal consciousness. The point is that modern technology has greatly changed man's life, extending the limits of freedom, thus giving rise to new problems. Nowadays, analytical study of the problems of deprivation of liberty allows identifying some basic forms of their existence, which often draw researchers' attention and study of which makes it possible to understand the essence of the phenomenon better. In particular, technical progress has led to a change in the communication capabilities of man and society in space and time. All these factors significantly raise the value of freedom and make its deprivation even more painful for any person. In addition, the problems associated with deprivation of freedom, are also closely connected with a certain system of values, which is a leading one to a particular society, where mentality plays a fundamental role.

In the modern global society there appeared a need of in-depth and comprehensive study of the characteristics of freedom and deprivation of freedom in social and philosophical aspect. However, we can not count on the successful solution of the problems of legislationimprovement without formation of legal consciousness among the whole population. "Nowadays philosophy and right have a great and responsible task - to organize peaceful and just coexistence of people on the face of the earth, as the current crisis reveals, first of all, a deep malaise of the modern legal consciousness" [6. P. 18].

The connection between freedom and legal consciousness determines complex tendencies in the development of the civilized man.

Problems connected with deprivation of liberty are also closely connected with a certain system of values, which is the leading one for a particular society. The fact is that the idea of historical progress which is uniquely identified by a significant part of philosophers with the system of development and strengthening of Western values is associated as "the end of history". However, in general, the utopian concept of "the end of history" and "universal state" by 
Fukuyama, although based upon the values of market and liberal democracy, clearly does not stand up the criticism in the face of aggravated national, cultural and religious identity of peoples against the background of the global crisis of civilization in the $21^{\text {st }}$ century [8. P. 67]. Even ardent ideologists of globalization ring alarm bells: "Nowadays the peoples of Europe are induced that justice requires them as "compensation" of their past sins, to open borders and share the shelter with the descendants of those who were oppressed by their ancestors, despite the number of those, who expressed the desire to come. Could Europeans reject irreconcilable demands of cultural Marxists? After all, they require from them neither more nor less than demographic, cultural and national suicide, of course, for the benefit of mankind" [1. P. 327]. The impact of the unconscious upon the sense of justice is expressed in varying degrees, as the unconscious itself has rather heterogeneous structure. Based upon the works of C.G. Jung it is possible to state that there exists the personal unconscious ( that includes information from the outside world that due to the low intensity of the level of consciousness did not implement repressed from consciousness repressed desires, thoughts, images and content that lost intensity and were forgotten), and the collective unconscious. Studying social and philosophical foundations of freedom and its deprivation, it is important to bear in mind that so-called archetypes are the main elements of the unconscious. Primary collective images, remnants in the memory that were formed by countless repetition of the similar mental processes, typical, basic forms of wellknown, always repeating emotional experiences that, as a rule, are inherent by the entire nations, and sometimes by the whole humanity are referred to them by C.G. Jung [10]. As the main elements of the collective unconscious, archetypes have sustainable influence upon legal consciousness and, as a result, basic stereotypes of legal consciousness, including its basic ideas prototypes of justice, represented in the rational form and providing cooperation of justice and the unconscious, appear.

To comprehend the essence of freedom and unfreedom there is a necessity to consider another important factor. Since archetypes are stable and are the main elements of the unconscious, it is possible to suppose that as a result of their influence on legal consciousness, special elements that have stable contents - basic stereotypes of justice, appear. They involve elements that include the basic provisions and prototypes of justice, presented in the rational form. All this fundamentally affects the understanding of freedom and unfreedom in the global world.

Ideas of freedom are also determined by the fact that curators of the world democracy arbitrarily deprive one or another authority its legitimacy, that is, sovereignty. In this case, is not important how correct and loyal the criteria are, it is important that legitimacy in the system is dated from the outside, and is selected from the outside as well. This fair play originally supposes rejection of sovereignty in favor of a curator, i.e. renunciation of power and its replacement by various formats of local autonomy. All this finally leads to distortion of the ideas of freedom, both an individual and the whole society. Only on this basis it is possible to take legal action on restriction of liberty as a natural reaction of society to anti-social actions of individual subjects.

Important implementation of freedom is to follow the idea of perfection. This idea is the basis of social consciousness of collectivist societies. Societies of this type are characterized by the institute of perfect personalities represented in such phenomena as pieces of advice from the best people, wise men, teachers and mentors. If a personality choses this implementation of 
freedom, than it assumes following its idea, the logos (the perfect state of the personality). Each personality from birth has his own individual idea, which is expressed in such a notion as a vocation [12. Pp. 24-25].

Ideas of freedom in inclusive state are determined by the fact that the dominant position is occupied by spirituality, goodness, virtue. Only those people, who succeeded in virtue, can manage inclusive state [2. P. 86]. Not by chance, the researchers note that if Western discourse of thinking constructs, in general, representative schemes filled by contrived informative content, in Russian Christian theological tradition and the philosophy, the real dialectic of the conscious and the unconscious is expressed, conforming itself at the every step of human activity. This dialectics accompanies the complex dynamics of development of personality's spiritual world, which consists in the ascent from the unconsciousness to the consciousness. In this regard, it is important to take into account that “... the theory of universal values that exaggerates the importance of ideals and standards of individualistic society life shows its internal inconsistency more and more" [11. P 230].

Thus, it is possible to make a conclusion that the problem of human freedom, as well as the conditions of its deprivation, is one of the leading problems of social philosophy, and it can not be solved without taking into account historical traditions, mentality, etc. of a specific society, i.e. the foundation on which ideas about freedom and unfreedom are formed in the long run.

\section{References}

1. Buchanan, P.J. Smert' zapada [The Death of the West]. M.: "Izdatel'stvo AST" LTD; SPb.: Terra Fantastica, 2003. P. 327

2. Verkhovsteva, T.E. Sobornost': russkaia traditsiia i russkii ideal [Conciliarity: Russian Tradition and Russian Ideal] / T.E. Verkhovsteva // Theory and History. 2004. № 3. P. 86.

3. Dzhemal G. DNK vremeni [DNA OF Time] // Odnako. 2011. 5 September. Pp. 20-21.

4. Dugin, A. Trudno byt' patriotom [It is Difficult to be a Patriot] // Literaturnaia Gazeta. 2004. 7-13 July.

5. Zaslavskaia, T.I. Izbrannoe: $V 2$ t. [Selected Works: in 2 vol.]. M.: ZAO "Izdatel'stvo "Ekonomika"”, 2007. Vol. 2.

6. Ilyin, I.A. O sushhnosti pravosoznoniia [On the Essence of Conscience of Law]. M.: Rarog", 1993 P. 18.

7. Nestereko, O.G. Obshchestvennoe soznanie i ego formy [Public Conscience and its Forms]/ O.G. Nestereko. M.: Politizdat, 1959.

8. Pfanenshtil' I.A., Pfanenshtil' L.N. Rossiia i globalizatsiia: problemy i perspektivy [Russia and Globalization: Problems and Prospects] // Culture of Information Society. Krasnoyarsk, 2003. C. 67.

9. Solovyov, V.S. Opravdanie dobra [The Justification of the Good]. M.: Institute of Russian Civilization, Algorithm, 2012. 656 P.

10. Jung, C.G. Soznanie i bessoznatel'noe [Consciousness and the Unconscious ]: translated from English: Collection of works / Introductory word by A.A. Alekseeva. SPb.: Renaissance, 1997.

11. Yatsenko, M.P. Globalizatsiia kak forma istoricheskogo protsessa i aksiologiia istorii [Globalization as a Form of Historical Process and Axiology of History] // Scientific Problems of Humanitarian Research. Scientific-Theoretical Journal. Issue 9. Pyatigorsk, 2010. P. 230. 
12. Yatsenko, M.P., Malinin, A.V. Problema sovershenstva v kontseptsii russkogo kosmizma [The Problem of Perfection in the Conception of Russian Cosmism] // Scientific Opinion. Scientific Journal. 2012. №12. Pp. 24-25.

\title{
Свобода как проблема правосознания: социально-философские аспекты проблемы в глобальном мире
}

\author{
А.А. Ефаркин \\ Сибирский федеральный университет \\ Россия, 660041, Красноярск, пр. Свободный, 79
}

\begin{abstract}
В статье исследуются особенности проявления свободы в современном обществе. Автор доказывает, что она тесным образом связана с уровнем правосознания и предполагает сочиально-философский уровень анализа. В частности, доказывается, что представление о свободе в России имеет ментальные и исторические особенности, которые сформировали современный комплекс проблем в правовой сфере.

В современном глобальном обществе назрела необходимость глубокого и всестороннего изучения особенностей свободы и несвободы в соииально-философском аспекте. Однако нельзя рассчитывать на успешное решение задач совершенствования законодательства без формирования у всего населения правового сознания.

Свобода всегда соседствовала с правовым нигилизмом. Дело в том, что антиподом правовой культуры является правовой нигилизм в его многообразных проявлениях и формах - от недооценки и неуважительного отношения к праву до его полного игнорирования и отрицания. Правовой нигилизм - это всегда и государственный нигилизм, поскольку отрицание права включает в себя, по существу, и отрицание государства как правовой организации публичной власти. Правовой нигилизм получил широкое распространение во многих странах, в том числе и в России.
\end{abstract}

Несмотря на то что проблема лишения свободы не была предметом непосредственного внимания российских консерваторов, они выявляли его особенности и характеризовали основные идеи. Законы, по их мнению, развиваются из психического источника, представляющего собой сложное и многогранное образование, выраженное в законах природного бытия, в том числе в законах психической деятельности - от сознательной до бессознательной.

В глобальном мире появляются новые тенденции, касающиеся свободы и ее лишения. Исследуя сущность человеческой свободы, можно говорить об определенном сходстве интернациональной миссии России, призванной распространять истину и справедливость по всему миру (на основе православия и самодержавия при иаризме - русский народбогоносец, на основе социальной справедливости в марксистско-ленинском понимании и в духе пролетарского интернационализма при советской власти). Наконец, вполне очевидные параллели между иарским и советским режимами напрашиваются и в государственнополитической области.

Глобализация вызвала также рост международных межправительственных и неправительственных организаций, которые призваны защищать человека как в обыденной ситуации, так и в период его заключения. К другим видам транснациональных факторов, которые оказывают растущее влияние на проблему лишения свободы, относят мигрантов, зарубежных туристов и профессионалов высокого класса (юристы, журналисты, инженеры, архитекторы, ученые, которые склонны придерживаться космополитических взглядов и 
образа жизни). Дело не только в сложности лишения свободы человека, который имеет, к примеру, двойное гражданство, но и в различных представлениях о необходимости лишения свободы как воспитательной функиии общества.

Проблемы лишения свободы тесно связаны также с определенной системой иенностей, которая является ведущей для конкретного общества. Для постижения сущности свободь и несвободы появляется необходимость учета ещуе одного важного фактора. Поскольку архетипь устойчивы и являются основными элементами бессознательного, то можно предположить, что в результате их влияния на правосознание возникают особые элементы, имеющие устойчивое содержание, - базовые стереотипы правосознания. К ним можно отнести элементы, включающче основные принципиальные положения, первообразы правосознания, представленные в рациональной форме. Все это принципиальным образом влияет на понимание свободы и несвободы в глобальном мире.

Важное оформление свободы состоит в идее следования совериенству. Эта идея является основой общественного сознания коллективистских обществ.

Ключевые слова: свобода, правосознание, этикоцентризм, правовой нигилизм, естественное право, соборное государство.

Научная специальность: 09.00.00 - философские науки. 